\title{
Katarzyna Górniak
}

Wydział Administracji i Nauk Społecznych

Politechnika Warszawska

\section{DZIAŁANIA ORGANIZACJI SPOŁECZNYCH WOBEC OSÓB BIEDNYCH I WYKLUCZONYCH SPOŁECZNIE - ODBUDOWYWANIE CZY TWORZENIE SIECI SPOŁECZNYCH}

\section{WPROWADZENIE}

Wykluczenie społeczne, któremu towarzyszy doświadczenie ubóstwa, będące przedmiotem moich zainteresowań, związane jest zazwyczaj z postępującym rozpadem więzi społecznych, sieci relacji i układów społecznych, w których funkcjonowała jednostka. Doświadczających wykluczenia społecznego w sytuacji ubóstwa cechuje zawężanie się pola społecznych kontaktów i ograniczanie go do wąskich wymiarów. Oznacza również trudności związane z pełnym uczestnictwem w życiu społecznym i różnych jego wymiarach - politycznym, społecznym, gospodarczym, kulturalnym. Definiowanie wykluczenia społecznego w kontekście więzi łączących jednostkę z innymi członkami i jej uczestnictwa w sieciach społecznych zyskuje obecnie na znaczeniu, gdyż współczesne społeczeństwo jest postrzegane właśnie jako siatka przenikających się wzajemnych zobowiązań oraz poziomych relacji społecznych, nie zaś jako hierarchiczne układy czy powiązania. Nowoczesne społeczeństwa - jak pisze N. Luhmann (1994: 32-33) - nie posiadają „,organu, który byłby centralnym ośrodkiem sprawczym. Jest to społeczeństwo pozbawione wierzchołka i ośrodka centralnego".

Jednostki różnicują się pomiędzy sobą w zależności od tego, jak dalece uczestniczą w owej siatce i jaką siłę, i charakter, mają ich więzy przynależności. Koncepcja wykluczenia społecznego odnosi się zatem przede wszystkim do relacji społecznych i wynikających z nich przynależności, mocno akcentując zagadnienie integracji. Ekskluzja oznacza w takim ujęciu wykluczenie ze relacji społecznych i prowadzi do dezintegracji owych więzi społecznych. Dlatego też niektórzy badacze zjawiska postulują, żeby w odniesieniu do wykluczenia uży- 
wać słowa dezafiliacja (Castel 1996: 775), jako trafniej oddającego naturę tych procesów ${ }^{1}$.

Nie ulega wątpliwości, że punktem wyjścia dla takiego postrzegania społeczeństwa były teorie systemowe, ze szczególnie cennym wkładem wspomnianego Luhmanna. Luhmann (1995a: 141) stał na stanowisku, że procesy rozwarstwiania się współczesnych społeczeństwa nie przebiegają wzdłuż wymiarów wertykalnych, ale wzdłuż funkcji horyzontalnych. Kategoria wykluczenia społecznego ma sens, ponieważ dotyczy społeczeństwa, które jest zróżnicowane w odniesieniu do różnych funkcjonalnych systemów, do których jednostka przynależy albo nie. Nie ma natomiast zastosowania, gdy społeczeństwo jest postrzegane poprzez stratyfikację opartą na układzie pionowym góra-dół, w którym jednostka zajmuje określoną, względnie trwałą, pozycję.

Podkreślmy zatem, że jednostka może przynależeć do różnych systemów i działać zgodnie $\mathrm{z}$ ich wymaganiami - w ujęciu Luhmanna posługiwać się ich kodem - dzięki posiadanym zasobom, a odmowa przynależności do jednego nie musi pociągać za sobą zerwania więzów z pozostałymi. W każdym razie nie stanowi to reguły wpisanej w naturę ekskluzji społecznej, choć nie można stwierdzić, że takie zjawisko nie występuje, a w praktyce ma miejsce relatywnie często, szczególnie w przypadku doświadczania biedy. Potwierdzają to zresztą liczne badania i ustalenia, że życie w ubóstwie uruchamiające wykluczenie z jednego obszaru życia społecznego, Luhmannowskiego systemu, pociąga za sobą wykluczenie z innych obszarów, i rozpoczyna się od ograniczenia intensywności działania. Rozpoczęty proces wykluczania wykazuje zatem tendencję do wzmacniania i rozprzestrzeniania się, zaczyna przypominać rozrastające się kłącze, którego końcówki zostały oderwane, co oznacza, że udziały w różnych systemach, obszarach czy sieciach społecznych jednak wzajemnie się warunkują, wpływają na siebie, tworząc układ naczyń połączonych. Poszczególne systemy będą zatem zamykać drzwi przed osobami ubogimi, co może skutkować przejściem od biedy epizodycznej do trwałej przynależności do underclass (Grotowska-Leder 2002). Jak pisał klasyk socjologii F. Znaniecki (1992: 8) w odniesieniu do bezrobotnych: „zmiany, które rola bezrobotnego wnosi w te związki (chodzi tu o sieci związków społecznych, które wiążą jednostkę z innymi - przyp. K.G.), wcześniej, czy później osłabią większość więzi, a wiele z nich zostanie zerwanych [...]. A więc im dłużej ktoś jest bezrobotny, tym trudniej mu uzyskać wystarczające poparcie społeczne w próbach ponownego wzniesienia się do pierwotnego poziomu".

W tym momencie należy zwrócić uwagę na to, że wykluczenie to nie tylko pewien stan, ale również, a może przede wszystkim, proces, który charakteryzuje się stopniowalnością. Wykluczenie nie jest statyczne, ale procesualne. Przejście

${ }^{1}$ Castel (2000) w ogóle dystansuje się od pojęcia ekskluzji społecznej uważając, że stanowi ono swoistą pułapkę (fallstricke), bowiem zgodnie z logiką prowadzi do dychotomicznego rozumienia, a tym samym nie wnosi nic nowego. 
z bycia „w” do bycia „poza” nie stanowi zatem jednorazowego i nagłego aktu. Wykluczenie jest rozciągnięte w czasie, ma wymiar temporalny i oznacza, jak pisze M. Xiberras (1993 za: Silver 1994: 533-534), stopniowe i następujące po sobie zanikanie więzi społecznych i symbolicznych, które wiążą jednostkę ze społeczeństwem, czyli lokuje się na kontinuum od zintegrowania, rozumianego jako bycie elementem sieci wzajemnych powiązań opartych na wzajemności i wymianie, do zakwestionowania przynależności i społecznego odłączania się jednostek.

Trudno jest jednak zaakceptować tezę o pełnym wykluczeniu i to niezależnie od głębokości doświadczanego ubóstwa czy innej trudnej sytuacji, bo jak pisze J. Grotowska-Leder (2002: 62) ,pełne wykluczenie jest tożsame tylko z fizyczną śmiercią, każdy żyjący człowiek, choćby przelotnie i krótkotrwale, pozostaje w jakiś relacjach z innymi ludźmi”. Jednakże można również zauważyć, że nagromadzenie się w procesie wykluczenia określonych momentów, stanów czy sytuacji powoduje, że ów proces przekształca się w określone położenie społeczne, które uniezależnia się od tego procesu. M. Kronauer (2002: 211) podał pięć takich znaczących punktów/zjawisk wpisanych w wykluczenie, które tworzą owo samodzielne położenie, a należą do nich: wyłączenie ze społecznie uznanych segmentów pracy, wyłączenie z sieci społecznych powiązań, wyłączenie z udziału w konsumpcji wynikające $\mathrm{z}$ obniżającego się standardu życia $\mathrm{w}$ odniesieniu do uznawanego poziomu, wyłączenie z podlegania politycznym i społecznym prawom, czy instytucjom, wyłączenie z podzielania społecznie akceptowanych i wyznaczanych celów życiowych. Wykluczonym nie pozostaje zatem nic innego, jak ,wpasowanie” się i przyjęcie danych uwarunkowań jako niezbywalnych, a ponadto, jak zauważa autor, zaczynają oni podejmować działania, które przyczyniają się do reprodukcji sytuacji, w jakiej się znaleźli, czyli utrwalać ten stan.

Niemniej postrzeganie wykluczenia społecznego w kontekście następujących zmian czy ograniczeń w obszarze sieci społecznych, ale również uczestnictwa i dostępu do instytucji społecznych, nie musi wcale oznaczać, że jest to proces nieodwracalny i niemożliwy do zatrzymania (Kronauer 2002: 46-47). Wykluczanie nie jest jednokierunkowe, co więcej, w ujęciu Luhmanna wykluczenie z jednego systemu czy sieci powiązań może pociągać za sobą przynależność do innego, np. wykluczenie ze sfery pracy często skutkuje wejściem w system instytucjonalnej pomocy i wsparcia. Możemy więc mówić nie tylko o trwale wykluczonych, wykluczonych z przerwami i przelotnie wykluczonych (Szarfenberg 2004: 6), przy czym zawsze należy zadawać pytanie, czego (jakiego systemu) wykluczenie dotyczy, ale również możemy wspominać o wykluczonych, którym udało się w pełni lub częściowo odbudować swoje uczestnictwo w życiu zbiorowym i zregenerować łączące ich z nim więzi. Owo odwracanie procesu wykluczania nie byłoby możliwe, gdyby nie działania zewnętrznych instytucji oferujących pomoc i wsparcie. W pierwszym rządzie należą do nich instytucje publiczne, ale ogromne znaczenie mają też organizacje pozarządowe, szerzej społeczne, których rola i znacznie zmieniały się historycznie. 


\section{ROLA ORGANIZACJI SPOŁECZNYCH}

Tak jak „sposoby doświadczania i rozumienia biedy są [...] kształtowane przez socjoekonomiczne konteksty strukturalne i kulturowe" (Lister 2007: 15), tak również sposoby zwalczania, przeciwdziałania i walki z biedą będą przyjmowały różne formy, w zależności od kontekstu społecznego czy istniejącego porządku społecznego i zasad go organizujących. Definicje określenia i wyobrażenia dotyczące osób ubogich i wykluczonych pociągają za sobą prawomocne propozycje działań, które mogą być wobec nich podejmowane. To, jak się pomaga w wychodzeniu z wykluczenia i biedy, jest pochodną rozgrywanych w danym momencie szerszych procesów czy zjawisk społecznych dotyczących zróżnicowanych kwestii: stratyfikacji i istniejących stosunków społecznych, więzi społecznych, roli jednostki, pojmowania solidarności i wspólnotowości czy systemu wartości. Działania podejmowane wobec biednych i wykluczonych stanowią odpowiedź na aktualnie definiowane problemy społeczne, ponieważ w innym przypadku nie zyskałby akceptacji społecznej.

Stwierdzenie E. Tarkowskiej (2002: 8), że „dążenie do ułatwiania egzystencji ubogich, do przeciwdziałania biedzie i jej skutkom to niejako inna, druga strona złożonego zjawiska, jakim jest bieda. Koncentracja na sferze pomocy i przeciwdziałania biedzie to tylko inna perspektywa w ramach całościowego poznawania biedy jako złożonego, wielowymiarowego zjawiska społecznego", koresponduje wprost z konstatacją R. Lister. Tym samym wykluczenie społeczne istnieje zawsze $\mathrm{w}$ powiązaniu z działaniami przeciwnymi czy odwrotnymi, czyli działaniami tradycyjnie nazywanymi dobroczynnością, a współcześnie wspieraniem czy pomaganiem. Te dwa procesy tworzą nierozerwalny układ, są jak rewers i awers.

Analizując przeobrażenia, które dokonały się w sferze działań pomocowych można zauważyć, że kluczowym momentem zarówno dla definiowania biedy, jak i roli biednych w społeczeństwie, a tym samym określania zakresu działań pomocowych, było zniesienie społeczeństwa stanowego. Proces ten uruchomił odmienne myślenie i interpretacje tego, kim jest osoba biedna i jakie jest jej miejsce w społeczeństwie. Kres społeczeństwa stanowego i pojawienie się nowych struktur społecznych opartych na odmiennych niż dotychczas regułach oznaczał diametralną zmianę $\mathrm{w}$ definiowaniu roli jednostki w społeczeństwie, należnych jej praw, możliwości działania, zakresu sprawstwa. Zmieniła się zatem również perspektywa określania i wizualizowania biedy i osób biednych, choć oczywiście bieda jako sytuacja społeczna, jako zjawisko nadal występuje i nic nie wskazuje na to, żeby miało przestać istnieć, ponieważ „W zależności od specyficznego modelu porządku i normy, każde społeczeństwo »tworzyło« swoich ubogich na własny obraz, oferując odmienne dla nich zastosowania i wykorzystując różne strategie stawiania czoła problemowi ubóstwo/a" (Bauman 2006: 189); nie ma zatem społeczeństw bez biedy. 
Wraz z zanikiem społeczeństwa stanowego zaniechano myślenia o człowieku biednym jako nieodzownej części układu społecznego. Obecność biednego $\mathrm{w}$ przestrzeni publicznej przestała być potwierdzeniem istniejącego porządku społecznego, a zaczął on być postrzegany najpierw - w schyłkowym okresie społeczeństwa feudalnego i rodzącego się społeczeństwa kapitalistycznego - jako zagrożenie porządku społecznego, a następnie w społeczeństwach kapitalistycznych, także rozwijającej się demokracji, jako rezultat niesprawności tegoż układu, zawodności istniejących procesów społecznych. Apoteoza i mitologizacja ubóstwa zostały zastąpione najpierw represją i przymusem (okres wczesnego kapitalizmu), bowiem „zmianę w dotychczasowym stanowisku wobec ubogich - od miłosierdzia wieków średnich do represji i przymusu ery nowożytnej należy traktować jako reakcje na wzrastająca liczbę ubogich" (Leś 2000: 221), a następnie przekonaniem o niezbywalnym prawie wszystkich osób do godnego życia, czyli życia bez biedy. Biedny stał się obywatelem i tym samym otrzymał prawo do egzekwowania wszystkich związanych z tym statusem uprawnień, w tym praw socjalnych; jego los mógł zatem ulec odwróceniu. Bycie biednym przestało być rolą społeczną daną raz na zawsze, a zaczęto je postrzegać jako sytuację, która nie powinna mieć miejsca $i$ jest przede wszystkim sygnałem niesprawności czy zawodności procesów społecznych ${ }^{2}$. I w tym sensie bieda stała się zbędna i niepasująca do współczesnych czasów. Bieda zyskała zatem miano problemu społecznego, czyli zjawiska niekorzystnego, niewłaściwego, społecznie nieużytecznego, ocenianego na ogół jednoznacznie negatywnie, które wymaga całościowych i systemowych interwencji. Interwencji, które miałby doprowadzić do wyeliminowania biedy i odwrócenia, a przynajmniej zahamowania procesu wykluczenia, który wprawia w ruch ${ }^{3}$.

Zmiana kontekstu społecznego tworzącego biedę, pociągnęła również zmianę w widzeniu roli nie tylko państwa, ale i organizacji (działań) społecznych, które istniały zawsze, tak jak zawsze istniała bieda. Organizacje społeczne, ażeby zyskać społeczną akceptację, musiały podporządkować się owemu kontekstowi,

${ }^{2}$ Nie oznacza to oczywiście, że martwe są przekonania odnoszące się do kategorii biedy zawinionej, odpowiedzialności za własny los, w tym za los biednego. Wręcz odwrotnie są nadal bardzo aktualne i stale obecne w dyskursie publicznym (patrz: Tarkowska 2013; Lister 2007; Bauman 2006, 2004).

${ }^{3}$ W tym ujęciu zbędność pociąga za sobą konieczność podejmowania działań odwracających sytuację biedy, jednak niektórzy analitycy współczesności pokazują pozorność tego typu myślenia i wskazują, że zbędność pociąga za sobą eliminację, a biedni jako nieprzydatni stanowią „odrzuty, odpady ludzkości”, które spotykają się tylko z odrazą i lekiem, ewentualnie nadal - litością, a nie reakcją pomocy i wsparcia, które zmieniłoby ich biografię. Ironicznie pisze o tej sytuacji Bauman „, i o to po raz pierwszy w zapisanej historii ubodzy stanowią i po prostu problem, i utrapienie. Nie mają zalet, które mogłyby łagodzić, a co dopiero zrównoważyć ich wady. Nie mają nic do zaoferowania w zamian za nakłady podatników. Są złą inwestycją, która najprawdopodobniej się nie zwróci, nie wspominając nawet o zysku: czarną dziurą wysysającą wszystko, z wyjątkiem może kłopotów. Przyzwoici i normalni członkowie społeczeństwa - konsumenci - nie chcą od nich niczego ani niczego nie oczekują. Ubodzy są całkowicie bezużyteczni” (Bauman 2006: 196). 
dopasować się do okoliczności, zacząć respektować owe społeczne wymogi. I to na trzech poziomach. Pierwszy kontekst odnosi się do wymogów dotyczących nowej roli jednostki w społeczeństwie i jej możliwości działania czy należnych praw, gdzie bieda nie jest traktowana jako stan naturalny czy konieczny dla istnienia ładu społecznego. Po drugie, organizacje musiały zacząć podejmować działania, które stanowiły przeciwwagę dla zjawisk tkwiących u podstaw mechanizmów wykluczenia, które czasami je wywołują, a niekiedy tylko wzmacniają lub im po prostu towarzyszą, ponieważ bieda przestała być tylko i wyłącznie zwykłą czy prostą deprywacją materialną. Jak stwierdza Kronauer, „powstanie problemu (ekskluzji społecznej - przyp. K.G.) nie jest logicznym rezultatem racjonalnie operującego systemu funkcjonalnego, ale historycznym rezultatem głęboko sięgających przeobrażeń, które zachodzą obecnie w wysoko rozwiniętych kapitalistycznych społeczeństwach" (Kronauer 2002: 134). Przeobrażania te, związane m.in. ze wzrostem indywidualizmu, zmiennością reguł i wymogów społecznych, zmiennością ryzyk społecznych, rozszerzającym się polem nieprzewidywalności, kurczącym i niestabilnym rynkiem pracy, stają się zatem wyzwaniem dla organizacji społecznych - wyznaczają ramy dla ich działań i stanowią ważne punkty odniesienia. Natomiast trzeci kontekst dla działań organizacji społecznych łączy się z wyłonieniem się struktur silnego i stabilnego państwa. Do tego czasu organizacje społeczne stanowiły de facto najważniejszy podmiot $\mathrm{w}$ działaniach $\mathrm{w}$ sferze biedy, natomiast obecnie to przede wszystkim państwo wraz z jego instytucjami jest odpowiedzialne za utrzymywanie porządku społecznego, w tym za wspieranie osób pozostających w trudnych sytuacjach, które nie mogą z tego powodu korzystać z przysługujących im praw obywatelskich oraz w pełni uczestniczyć w życiu społecznym. Organizacje społeczne natomiast $\mathrm{w}$ owym procesie współuczestniczą, choć zakres ich autonomii, przynajmniej formalny, jest bardzo szeroki. Mogą zatem zarówno wspierać działania służb publicznych, działać zgodnie z ich celami, jak i tworzyć własne rozwiązania instytucjonalne i poszerzać ofertę publicznego systemu pomocy i wsparcia (por. Leś 2000; Golczyńska-Grondas 2012/2013).

Analizując ogólny dyskurs dotyczący roli organizacji pozarządowych w działaniach na rzecz ludzi ubogich można zauważyć, że zasadnicze przejście polegało na tym, że organizacje te przestały odwoływać się do miłosierdzia, współczucia i litości, a zaczęły postrzegać swoje zdania w kategoriach naprawy, powrotu biednych do społeczeństwa - w dyskursie instytucjonalnym mówi się o integracji społecznej, reintegracji, inkluzji. Rola organizacji polega wobec tego nie na sankcjonowaniu (utrwalaniu) biedy, ale na jej kwestionowaniu, podważaniu jej istnienia i trwałości, dążeniu do zniesienia. W rezultacie śledząc rozwój organizacji społecznych, czyli owego stałego elementu działań pomocowych można zauważyć, że przeszyły one „ogromną ewolucję - od świadczenia doraźnej i uznaniowej pomocy filantropijnej do realizacji ustawowych świadczeń i usług społecznych w ramach powojennego państwa welfare i państwa subsydiarnego" (Leś 2000: 231). 
Jeśli zatem uznamy metaforę „powrotu do społeczeństwa osób biednych” jako trafnie wyrażającą cele i założenia, które leżą u podstaw działań organizacji społecznych, to możemy je postrzegać jako instytucje, które dążą do odbudowywania sieci i społecznych przynależności, w jakich funkcjonowały czy powinny funkcjonować jednostki, ułatwiają im ów powrót poprzez dostarczanie odpowiedniego wsparcia i pomocy. Działania pomocowe podejmowane przez organizacje społeczne powinny zatem dawać szansę czy umożliwiać osobie biednej życie zgodne $\mathrm{z}$ akceptowalnymi standardami, odzyskać pełnoprawność uczestnictwa w życiu społecznym. Odwołując się ponownie do Luhmanna i przyjmując jego systemowe spojrzenie, organizacje społeczne winny stanowić współcześnie rodzaj systemu pośredniczącego pomiędzy wykluczeniem a inkluzją, być złączem pomiędzy przeszłością, która doprowadziła do doświadczenia biedy, a przyszłością, w której owo doświadczenie nie wystąpi. Tworzyć swoisty interfejs otwierający biednych na nowe życie i przygotowujący na wyzwania i wymogi innych systemów oraz tworzonych przez nie sieci społecznych, wyposażać biednych w kody potrzebne do harmonijnego i samodzielnego komunikowania się w tych systemach czy sieciach. Działania pomocowe podejmowane przez organizacje społeczne tworzyłyby w takim ujęciu system, ale nie domykający się, tylko pełen wypustek i furtek z napisem „wyjście”; wypychający wręcz swoich uczestników.

Powyżej sformułowane oczekiwania co do roli organizacji społecznych zgodne są zatem z opisaną pokrótce logiką procesów społecznych i założeniem, że tak jak każde społeczeństwo tworzy własne definicje biedy, tak też tworzy powiązany z tymi definicjami model pomocy. Poznawczo interesujące jest jednak to, na ile jednak owe społeczne wymogi i interpretacje statusu biedy i pomocy w sytuacji biedy zbieżne są z przekonaniami, refleksją i praktyką samych organizacji, w jakim zakresie, lub czy w ogóle, wpisują się one w ten instytucjonalny dyskurs o biedzie i sposobach jej przeciwdziałania. Interesujący jest zatem ów „ukryty program" organizacji społecznych, czyli to co istnieje poza oficjalnymi deklaracjami, założeniami czy celami manifestowanymi w sferze publicznej, co jest praktykowane w sposób mimowolny i odnosi się do głęboko zinternalizowanych wartości i przekonań.

Odpowiadając na pytania dotyczące realnej roli organizacji społecznych, odwołano się do materiału empirycznego pozyskanego w trakcie realizacji projektu badawczego „Dyskursy ubóstwa i wykluczenia”"

${ }^{4}$ Projekt badawczy „Dyskursy ubóstwa i wykluczenia społecznego” (nr 2747/B/H03/2010/38) realizowany był w Instytucie Filozofii i Socjologii PAN pod kierownictwem prof. E. Tarkowskiej. Analiza dyskursu formułowanego przez organizacje pozarządowe została dokonana na podstawie wywiadów pogłębionych, częściowo o charakterze biograficznym, z przedstawicielami tychże organizacji. Łącznie przeprowadzono dwadzieścia wywiadów z założycielami poszczególnych organizacji, jak i osobami długo pracującymi z biednymi. Analiza (interpretacja) wypowiedzi odnosiła się natomiast do założeń i perspektywy krytycznej analizy dyskursu. Szczegółowy opis założeń 


\section{DEKLARACJE I ZOBOWIĄZANIA}

Pojęciem, które w bardzo dużej mierze organizowało wypowiedzi przedstawicieli organizacji społecznych $\mathrm{w}$ odniesieniu do definiowania swojej roli, było pojecie „,zmiany”, która poprzez uczestnictwo w proponowanych osobom biednym działaniach powinna u nich nastąpić. Zmiana ta miałaby doprowadzić do odzyskania przez biednego samodzielności, sprawczości oraz pozyskania czy wypracowania zasobów niezbędnych do uczestnictwa w systemach czy sieciach społecznych, z których została wykluczona. W konsekwencji zaś, do stania się pełnoprawnym ich aktorem. To znaczy takim, który nie tylko ów dostęp uzyskuje, ale może z niego również korzystać, swobodnie operować w ramach różnych systemów, rozumie ich zasady (kody) i jest w stanie sprawnie się nimi posługiwać.

Owa zmiana następuje poprzez zakwestionowanie przez osobę biedną swojego dotychczasowego sposobu życia i praktykowanych strategii radzenia sobie $\mathrm{z}$ biedą, ponieważ $\mathrm{w}$ perspektywie organizacji społecznych przyczyniają się one do utrwalania i reprodukcji doświadczenia biedy. Są nielogiczne i nieracjonalne z punktu widzenia logiki systemów, do których jednostka chciałby znowu przynależeć. Tym samym

naszą rolą jest by zmienić myślenie i tu jest duża praca (P1) brak objaśnienia, człowiek jednak podejmuje wysiłek, zmienia się, zmienia się jego optyka, perspektywy [...] nabiera kompetencji, rozlicza się z przeszłością, przejmuje za siebie odpowiedzialność [...] żeby ten człowiek podjął trud, to jest najważniejsze i najtrudniejsze (W1).

Przedstawiciele organizacji społecznych są zatem co do tego zgodni, że zmiana, która dokonuje się w biografii osoby biednej, polega na wyjściu ze sfery wpływów i oddziaływania tychże organizacji. Chociaż równocześnie świadomi są również tego, że jest to proces trudny i stopniowalny, a owa nić łącząca biednego $\mathrm{z}$ organizacją będzie długo aktywna:

ona już na tyle osiągnęła poziom samodzielności, że potrafi zadbać o swoje sprawy i to jest tak, że widać, że ona pracuje, już tam sobie poukładała, jest w stanie samodzielnie się utrzymać, osiągnęła wiedzę z powrotem o świecie, rzeczywistości tak, że potrafi się tam odnaleźć, potrafi skorzystać ze swoich praw, wkluczyć się w jakieś działania, wie, gdzie szukać na przykład różnej tam pomocy, czy gdzie się udać, żeby załatwić jakąś sprawę. Czyli tą pełnie wiedzy obywatelskiej na dzień dzisiejszy potrafi uzyskać, wykorzystać i jest na tyle odpowiedzialna. Natomiast można jeszcze wsparcia i takiego emocjonalnego i informacji udzielać osobie, która już pracuje, już ma tam wszystko jakoś poukładane, ale trochę się jeszcze gubi w tej całej rzeczywistości, która dla niejednego jest trudna (P2).

badawczych oraz metodologii znajduje się w publikacji pod redakcją E. Tarkowskiej (2013), a opis badania dotyczącego dyskursu organizacji pozarządowych w jednym z tekstów (Górniak 2013). Część dotycząca odwołań do badań empirycznych w niniejszym artykule stanowi jednak nie tyle przywołanie opisanych już wniosków, ale ujęcie i interpretacja materiału badawczego zgodne z założeniami i celami tego artykułu. 
Reprezentanci organizacji pozarządowych, mówiąc o usamodzielnianiu osoby biednej i odzyskiwaniu przez nią pełnoprawnego uczestnictwa (werbalizowane cele), równocześnie kwestionują zdolność do osiągnięcia jej przez osoby biedne, wskazując, że ich praca ma w rzeczywistości charter syzyfowy. Wyrażają tym samym przekonanie, że powrót ze ścieżki wykluczenia jest bardzo trudny i napotyka na wiele barier, niekiedy wręcz staje niemożliwy, a to głównie ze względu na właściwości samej osoby biednej - jej deficyty, nawyki, zaniedbania czy braki. Historie osób, którym udało się odzyskać samodzielność i które zaczęły normalnie funkcjonować są zatem przytaczane raczej dla potwierdzenia zasady, że wyjątek potwierdza regułę, a nie jako ilustracja typowej i powszechnej ścieżki wychodzenia $\mathrm{z}$ wykluczenia.

Osoby biedne wymagają zatem nieustannego i ciągłego wsparcia, mobilizowania, aktywizowania:

większość z tych osób wraca ciągle do schroniska i rzadko, która osoba rzeczywiście będąc poza schroniskiem zostanie tam na zawsze (G2), zakładamy, że wobec części [...] całe życie będą potrzebowali pomocy, wsparcia całe życie. Tylko chodzi o to, żeby oni raz: potrafili, samodzielnie żyć, w jak największym stopniu. I żeby ta pomoc była ograniczana. Ale na przykład tu są takie grupy, nigdy Pan nie będzie mógł przerwać tej pomocy, tylko no w różnych formach ona jest świadczona (W1).

Ponieważ w przeciwnym wypadku ów proces wykluczania będzie się pogłębiał i intensyfikował. Działania organizacji społecznych można zatem w takim ujęciu postrzegać jako przede wszystkim zapobiegające utrwalaniu i rozszerzaniu się skali wykluczenia, niekiedy również jako odwracające ten proces, choć rzadko w sposób całościowy, ale też jako mogące istnieć właśnie dzięki owemu systemowi wykluczeń i obejmowaniu swoją uwagą owej rzeszy wykluczonych.

\section{PRAKTYKI I STRATEGIE POMAGANIA}

Analiza wymienianych i opisywanych przez przedstawicieli organizacji społecznych działań skierowanych do osób ubogich pozwala wyodrębnić cztery przyjmowane przez nich strategie, czy podejścia, i towarzyszące im praktyki, które nie są w pełni rozłączne, ale które koncentrują się na odmiennych aspektach udzielanego wsparcia. Są to działania doraźne, pośredniczące, normalizujące i wspólnotowe.

Pierwsza grupa działań, tj. działania doraźne, nie ma charakteru systemowego czy całościowego, a wynika z tymczasowych potrzeb zgłaszanych przez osoby ubogie. Ale odnosi się tak do potrzeb elementarnych, podstawowych, których spełnienie jest podstawą przeżycia w wymiarze biologicznym, jak i potrzeb niejako wyższego rzędu, czyli tych, które wiążą się z szerszymi aspektami życia. 
Działania doraźne umożliwiają zatem zarówno przeżycie, jak i samo życie. Nierzadko też stanowią punkt wyjścia do dalszej pracy z osobą biedną. Mają za zadanie ułatwiać funkcjonowanie $\mathrm{w}$ świecie zewnętrznym i wchodzenie $\mathrm{w}$ owe pozamykane sieci społeczne, np. osoba biedna, ale ubrana w akceptowalny społecznie sposób może ubiegać się o pracę, dziecko, która posiada pomoce szkolne, może uczestniczyć w systemie edukacyjnym.

Organizacje społeczne zajmują się zatem dożywianiem, zarówno poprzez rozdawanie żywności, jak i prowadzenie jadłodajni czy punktów, gdzie można zjeść posiłek przy okazji innych zajęć, dostarczaniem ubrań, pomocy szkolnych, środków czystości, finansowaniem opału, czynszu, ale też operacji czy leczenia. Starają się pozyskiwać, organizować i dostarczać wszystko to, co będzie wykluczonym potrzebne:

odzież, żywność, ale też przychodzą jak nie mają na prąd, nie mają na gaz. [...]. Czy nie mają dla dzieci zeszytów, książek. Pomagaliśmy w rehabilitacji, [...] i w remoncie domu. Ja to mówię zawsze, łatwiej byłoby wymienić, co myśmy nie robili. Bo to już się przygotowywało dzieci do komunii, a trzeba było i ubrać i iść do kościoła, bo mama leżała tam pod stołem, a dziecko chciało też iść z rówieśnikami. Czyli pogrzeby i różne sytuacje losowe od momentu narodzin aż do jego śmierci. Tak, że u nas wszystko było (K1).

Zauważyć jednak należy, że to organizacje same decydują o tym kto i w jakim wymiarze czy jakiego rodzaju pomocy potrzebuje. Osoba biedna zgłasza swoją potrzebę, natomiast organizacja rozstrzyga, po pierwsze, czy ta potrzeba zasługuje na pomoc i zainteresowanie, jaka jest jej ważność i, po drugie, w jaki sposób będzie zaspokojona. Tym samym osoby, które próbują same zdefiniować, czego im potrzeba, określane są zazwyczaj mianem roszczeniowych, tupeciarzy, spryciarzy:

oni do nas przychodzą, oni się domagają, że im się należy [...] On nie prosi, tylko żąda. Raz się śmiałam bo przyszła taka pani [...], która miała 7 dzieci i przyszła do mnie z kartką [...]. I miała zapisane kosmetyki, takie dobre kosmetyki [...] to mnie najbardziej drażni, że wie pani, to widać, takie naciągacze, że to pójdzie wszędzie, obejdzie wszędzie, to tak jak pani, która ma 7 dzieci też ma córki dorosłe i mówię: ,załatwiłam pracę”, bo tak jej ciężko, bo jej tam odcięli gaz, pomogłam zapłacić prąd, raz jej żeśmy opał załatwili, bo ciągle ktoś chory, wypadki, ciągle coś się działo. W końcu ja mówię, pomożemy pani załatwić pracę. Załatwiłam pracę dla córki. Nie, jej córka nie po to się uczyła, a jak się później dowiedziałam miała zawodówkę skończoną, nie po to jest wyedukowana, żeby dzieciom tyłki obcierała (K1).

Takie podejście wynika przede wszystkim z postrzegania osób biednych jako nieumiejących racjonalnie, to jest zgodnie z obowiązującymi zasadami i logiką systemową, postępować, tym samym chroni organizację przed marnotrawieniem udzielanej pomocy.

Biedni definiowani są również przez przedstawicieli organizacji społecznych jako osoby zagubione w rzeczywistości społecznej, nieznające lub nierozumiejące obowiązujących wytycznych będących regulatorami życia, nie dysponują kom- 
petencjami, które umożliwiałby im nawiązywanie satysfakcjonujących kontaktów ze światem społecznym, komunikowaniem się z nim. Są zatem postrzegane jako niezaradne i to określenie jest jednym $\mathrm{z}$ wiodących $\mathrm{w}$ mówieniu o biedzie $\mathrm{i}$ osobach biednych. Tym samym potrzebują działań, które łączyłby ich z owym nieprzyjaznym światem zewnętrznym, jego systemami i wpisanymi weń instytucjami.

Organizacje pozarządowe lokują się w takim ujęciu w roli thumacza reguł, pośrednika (działania pośredniczące) pomiędzy wykluczonym, który nie ma wiedzy dotyczącej funkcjonowania świata instytucji, jak również nie potrafi posługiwać się jego kodem, komunikować się z nim, co w konsekwencji prowadzi do rezygnacji z przysługujących mu praw i domagania się ich respektowania, a właśnie owym światem instytucji, który rządzi się własnymi regułami, jest hermetyczny, stawia wymagania i nie zauważa osób, które nie są w stanie się do niego dostosować. Z wypowiedzi badanych wynika, że wykluczony dla świata instytucji innych systemów nie istnieje, w zetknięciu z nimi jego sprawczość, siła przebicia są bardzo słabe, staje się niewidoczny. Dla urzędnika czy pracownika instytucji, np. banku, szkoły, urzędu pracy nie jest on partnerem, z którym można by nawiązać równościową relację. Organizacje społeczne, wyjaśniając i tłumacząc reguły otaczającej rzeczywistości społecznej zarówno towarzyszą ubogim we wchodzeniu w tę rzeczywistość, jak i są ich reprezentantami:

pomagamy na przykład dokumenty wyrobić, informujemy, jak to trzeba zrobić [...] jak są niezarejestrowane w Urzędzie Pracy, to pomagamy zebrać dokumenty i żeby się rejestrowały. Które osoby mogą starać się o świadczenia tego typu, żeby dostać zasiłek stały lub rentę, to też pomagamy w kompletacji, w wypełnieniu dokumentów (P2), On miał bardzo dużo zadłużenia alimentacyjnego. To było ponad 100 tysięcy i wszystko udało się nam umorzyć. Tak, że wychodzi stąd nie mając długów (LE2), przyszli tacy ludzie, którym odcięto prąd i nie wiedzieli, jak to załatwić, bardzo biedni ludzie $(\mathrm{CH} 2)$.

Ponieważ w podejściu reprezentantów organizacji społecznych bieda, która towarzyszy wykluczaniu, związana jest z niezdolnością do budowania wspólnoty doświadczeń (biedni mają inny zakres doświadczeń życiowych i społecznych niż osoby niebiedne, co zasadniczo utrudnia wzajemną komunikację i możliwość nawiązania porozumienia), toteż bardzo duże znaczenie przypisują oni przedsięwzięciom, których celem jest tworzenie sytuacji czy przestrzeni do podejmowania działań akceptowalnych społecznie, takich jak dla osób niebiednych oraz tak, jakby czyniły to osoby niebiedne. Organizacje społeczne starają się zatem normalizować deficyty doświadczeń życiowych, wyrównać sytuacje osób biednych poprzez dostarczanie im możliwości podejmowania działań ze świata „normalnych". Ale też w ten sposób upowszechniają społecznie akceptowalne wzory postępowania (aspekt edukacyjny), pokazują biednym, jak należy się zachowywać, reagować, czy działać w określonych sytuacjach.

Owe działania normalizujące odnoszą się zarówno do sytuacji codziennych, jak i wyjątkowych, odświętnych. Na poziomie codzienności oznaczają przede 
wszystkim tworzenie sytuacji mieszczących się w typowych wzorach funkcjonowania w życiu społecznym i udostępnienie ich wykluczonym. Polegają zatem m.in. na prowadzeniu miejsc, gdzie można zjeść posiłek przy stole (obrus, talerze, sztućce), chodzeniu do parku na spacery, chodzeniu do kina, oglądaniu filmów wyświetlanych z projektora, muzykowaniu, spotkaniach przy herbacie i ciastkach (namiastka kawiarni), uprawianiu gimnastyki (fitness), powadzeniu pracowni zainteresowań dla dzieci (np. modelarska), korzystaniu z Internetu. Natomiast w odniesieniu do odświętności polegają na organizowaniu świąt (Wigilia, śpiewanie kolęd), obchodzeniu uroczystości, organizowaniu wyjazdów wakacyjnych:

na walentynki zrobiłam spotkanie walentynkowe i zatytułowałyśmy to liryka miłosna, aczkolwiek nie była to wyłącznie poezja. Ale osoby mogły się pochwalić jakimiś, jakąś recytacją, jakimiś dowcipami, nawet kawałami jakimiś na temat miłości, opowiastkami (L2), spotkania opłatkowe (S2), wiele mam dzieci takich, które nie widziały morza [...] my organizujemy od początku kolonie, obozy. Byliśmy już na Słowacji, na Ukrainie z wymiany międzynarodowej i nad morzem (K1).

Analizując owe działania normalizujące, wyrównujące sytuacje wykluczonych na poziomie doświadczania określonych zachowań czy przeżyć, należy jednak zauważyć, że ich praktykowanie zamyka się w obrębie samych wykluczonych, skierowane jest do tych, którzy są w orbicie oddziaływania organizacji, którzy korzystają z jej wsparcia. W konsekwencji wykluczeni doświadczają tego, co inne osoby, ale nie z nimi, tylko we własnym otoczeniu, razem ze sobą. Organizacje koncentrują się na dostarczaniu wykluczonym możliwości doświadczania i przeżywania społecznych zachowań czy rytuałów, ale już niekoniecznie na ich relacjach i komunikowaniu się z osobami ze świata zewnętrznego i z nim samym.

Działania normalizujące prowadzą zatem często do budowania wspólnoty biednych mniej lub bardziej zamkniętej na kontakty z otaczającą je rzeczywistością, w której obrębie odbywa się znaczna część aktywności, np. mieszkanie, praca, rozrywka. Uzasadnień dla takich praktyk można poszukiwać w przekonaniu, że osoby biedne ze względu na rozmiar swoich deficytów, braków, ograniczeń nie są w stanie nawiązywać poprawnych kontaktów ze światem, który jest wokół nich i komunikować się z oraz $\mathrm{w}$ nim. Zatem próby wejścia $\mathrm{w}$ tę rzeczywistość będą się zazwyczaj kończyć przykrymi porażkami lub rozczarowaniami, będą stanowić potwierdzenie ich ułomności, a nie pełnoprawności i akceptacji.

W świecie zewnętrznym osoba wykluczona spotka się zazwyczaj z niezrozumieniem, dlatego należy, według przedstawicieli organizacji społecznych, stworzyć warunki na miarę jej potrzeb i możliwości reagowania czy działania. I im głębsze i bardziej dotkliwe wykluczenie, im bardziej niestandardowe doświadczenia i trudności przeżywają osoby, tym konieczność tworzenia wspólnoty jest 
pilniejsza, bo nawet szablonowe działania podejmowane przez publiczne służby stają się nie tylko niewystarczające, albo wręcz szkodliwe:

z praktyki wiemy, że jak nasi panowie trafiają do takich domów pomocy społecznej, to jest tak inny świat, dla nich taki stres, że oni w przeciągu 2-3 miesięcy, do pół roku umierają. [...] w momencie gdy taki człowiek trafia - już doprowadzony przez nas do normalnego funkcjonowania - trafia do domu pomocy społecznej, to on tam zaczyna chudnąć, zaczyna się gubić i umiera, i umiera, co najgorsze - umiera. Wobec czego jesteśmy przekonani, że nie domy pomocy społecznej, te standardowe takie extra, wykafelkowane, z dziesięcioma pielęgniarkami na każdego pacjenta czy beneficjenta, tylko specjalne domy dla bezdomnych stałego pobytu, o charakterze domów pomocy społecznej [...] nie jest to moralnie, powiedzmy, wskazane, żeby go tam pakować, bo to jest tak, jakby - no, bardzo ostro to zabrzmi - jakbym kazał do komory gazowej go skierować (G1).

Działania wspólnotowe skierowane do ludzi biednych stanowią zatem, z jednej strony, odpowiedź na nieprzewidywalny i nieprzyjazny świat systemów społecznych, ale też wynikają z przekonania, że doświadczenie ubóstwa i wykluczenia społecznego są niezbywalne, albo ujmując to inaczej - możliwe do pokonania, ale w obrębie wspólnoty (systemu) stworzonego dla biednych, owego przypisanego im mikroświata.

\section{PODSUMOWANIE}

Wracając do kluczowego dla tej krótkiej rozprawy pytania, jak organizacje społeczne - ów bardzo znaczący aktor działający w obszarze pomocy osobom biednym i wykluczonym oraz biorący aktywny udział w dyskursie odnoszącym się do tych kwestii - widzą swoją rolę, przywołam jeszcze raz perspektywę zaproponowaną przez Luhmanna. Uważam, że jego spojrzenie może być bardzo pomocne w interpretacji uzyskanych wyników w przedmiotowej sprawie. W perspektywie tej działania, praktyki i strategie podejmowane przez organizacje społeczne tworzyć będą system (tradycyjnie nazywany dobroczynnym, współcześnie raczej pomocowym), a logika systemu jest nieubłagalna. System, żeby istnieć, musi wyodrębnić się z otoczenia, przede wszystkim poprzez odróżnienie się zarówno od samego otoczenia, jak i innych systemów. Nie może być zatem przepustowy - pełnić roli pośrednika czy łącza pomiędzy innymi systemami. Dlatego też przedstawiciele organizacji społecznych wielokrotnie powtarzają i akcentują w swoich wypowiedziach, że proces wykluczenia jest bardzo trudny do odwrócenia, a biedni ze względu na swoje liczne negatywne przymioty nie mają możliwości zaistnieć w innych systemach. Będą tam zawsze nieprzystającymi obcymi. Ale też owe inne systemy nie są otwarte na niepełnych czy ułomnych uczestników. W konsekwencji biedny jest definiowany jako ktoś zbędny, nieprzydatny, odpad w rozumieniu Baumana. 
W konsekwencji mamy do czynienia z poziomem deklaracji i na tym poziomie organizacje zgadzają się z rolą interfejsu dla osób biednych i skłonne są przyznać, że ich działania powinny odbudować zerwane sieci społeczne osób biednych i umożliwić im wejście do innych systemów, ów metaforyczny „powrót do społeczeństwa”. Równocześnie bardzo szybko zastrzegają, że jest to zadanie bardzo trudne, a w wielu przypadkach i sytuacjach wręcz niemożliwe. Stanowi to dobrą przesłankę do realnego kierowania się zupełnie innymi założeniami i kryteriami. Mianowicie analiza praktyk i rekonstrukcja „ukrytego programu” pozwala na sformułowanie wniosku, że organizacje społeczne zamiast stać się narzędziem do odbudowywania sieci społecznych osób biednych, tworzą alternatywny świat z własnymi sieciami, powiązaniami, ale też regułami dostępu. A uczestnictwo w nim w dużej mierze utrudnia wejście w inne systemy.

\section{BIBLIOGRAFIA}

Bauman Z. (2004), Życie na przemiat, Wydawnictwo Literackie, Kraków.

Bauman Z. (2006), Praca, konsumpcjonizm i nowi ubodzy, Wydawnictwo WAM, Warszawa.

Castel R. (1996), Nicht Exklusion sondern Desaffilation. Ein Gespräch mit F. Erwald, „Argument”, Nr. 217.

Castel R. (2000), Die Fallstricke des Exklusionsbegriff, „Mittelweg” 36, Nr. 3.

Golczyńska-Grondas A. (2012/2013), Polski trzeci sektor a profesjonalne pomaganie, „Kwartalnik Trzeci Sektor", numer specjalny.

Górniak K. (2013), Bieda i wykluczenie społeczne w perspektywie (dobroczynnych) organizacji pozarządowych, [w:] E. Tarkowska (red.), Dyskursy ubóstwa i wykluczenia społecznego, Wydawnictwo IFIS PAN, Warszawa.

Grotowska-Leder J. (2002), Fenomen wielkomiejskiej biedy, Wydawnictwo Uniwersytetu Łódzkiego, Łódź.

Kronauer M. (2002), Exklusion. Die Gefährdung des Sozialen im hoch entwickeltem Kapitalismus, Campus Verlag, Frankfurt-New York.

Leś E. (2000), Od filantropii do pomocniczości. Studium porównawcze rozwoju działalności organizacji społecznych, Dom Wydawniczy Elipsa, Warszawa.

Leś E. (2001), Zarys historii dobroczynności i filantropii w Polsce, Wydawnictwo Prószyński i S-ka, Warszawa.

Lister R. (2007), Bieda, Wydawnictwo Sic!, Warszawa.

Luhman N. (2007), Systemy społeczne zarys ogólnej teorii, Zakład Wydawniczy Nomos, Kraków.

Luhmann N. (1994), Teoria polityczna państwa bezpieczeństwa socjalnego, PWN, Warszawa.

Luhmann N. (1994), Teoria polityczna państwa bezpieczeństwa socjalnego, PWN, Warszawa.

Luhmann N. (1995), Jenseits von Barbarei, w: Gesellschaftsstruktur und Semantik. Studien zur Wissenssoziologie der modernen Gesellschaft, Bd. 4, Suhrkamp, Frankfurt am Main.

Luhmann N. (1997), Die Gesellschaft der Gesellschaft, Suhrkamp, Frankfurt am Main.

Silver H., (1994), Social Exclusion and Social Solidarity: three Paradigms, „International Labour Review", no. 5/6.

Tarkowska E. (red.) (2013), Dyskursy ubóstwa i wykluczenia społecznego, Wydawnictwo IFIS PAN, Warszawa.

Znaniecki T. (1992), Socjologia bezrobotnych, „Kultura i Społeczeństwo”, nr 2. 


\title{
NGOs' framework of action towards the poor and marginalized - reconstruction or formation of social networks
}

\begin{abstract}
Summary
Social/non-governmental organizations are one of important social actors operating in the field of poverty and social exclusion and taking active part in the discourse pertaining to these issues. Traditionally they are expected to undertake actions that support and facilitate ,getting out of poverty”, including rebuilding social ties.

Therefore, the purpose of my paper is to examine how contemporary non-governmental organizations see their own role in the context of constructing definitions of poverty and exclusion, in particular in relation to the task of equipping the beneficiaries of their activities with this important capital of ties and social relations. I analyze the extent to which this role is defined as a particular interface connecting the poor with the society and its networks, opening them up to new challenges and experience, rebuilding the world of belonging (ties), and how much it is perceived as an independent system that offers alternative solutions and rules of the game, creating its own social network, which in consequence can result in rendering the social ties/networks a barrier to the process of inclusion.

Niklas Luhmann's perspective and structure of analytical categories will be helpful in responding to these questions. It will allow me to describe the mechanisms of reconstructing and/or forming social ties within the framework of action of social organizations.
\end{abstract}

Keywords: poverty and social exclusion, social inclusion, non-governmental organizations, social support, social ties, social system. 